to the common denominator; and it is shown, for example, that in the Limfjord the annual increase in weight of the plaice is only about one-sixth of the amount of organic matter consumed, and that the annual consumption of the plaice and eel together is only about one-ninth of the nourishment available.

The work is stated to be in its beginning, and this report is to be regarded as the introduction only; even so, it is remarkable for its broad and philosophic insight into fisheries problems and its wealth of ideas and practical suggestions. It can be strongly recommended to the planktologists-as an antidote.

$\mathrm{K}$.

\section{SCIENTIFIC WORK OF THE IMPERIAL INSTITUTE}

IVE have received a copy of the " Report on the Work of the Imperial Institute, 1910" (Cd. 5467-23), which contains a prefatory statement describing the organisation and objects of the institute, and includes summaries of the investigations carried out by the scientific and technical staff during the year. These comprised the examination of various minerals; of vegetable products such as cotton, rubber, oils, tobacco, foodstuffs, and so forth and of a few animal products, including sponges, shells, feathers, and hair. Among the minerals mention is made of thorianite from Ceylon, containing $5 \mathrm{I} \cdot \mathrm{I}$ per cent. of thoria and 24.9 per cent. of uranoso-uranic oxide, the case being of special interest as indicating the kind of rock with which thorianite may be expected to occur in other localities.

Deposits of lignite from Southern Nigeria have been found to yield briquettes of excellent quality, and it is now clear that the use of local fuel, by obviating the heavy expenditure on imported coal, will materially assist the development of the West African colonies.

In the East African Protectorate an immense deposit of " soda" is to be worked; it consists essentially of sodium sesquicarbonate, and merely requires heating to furnish commercial " soda" of good quality. Numerous samples of rubber were examined, though only one actual consignment of any magnitude is described; this consisted of about $650 \mathrm{lb}$. of Landolphia rubber from the Bahr-elGhazal, which was of good chemical quality and realised fair prices.

In connection with the production of lemon-grass oil, the report states that the cultivation and distillation of lemongrass in Uganda is now securely established. Samples of wheat from the East African Protectorate and from Northern Nigeria were found to be of excellent quality, and some "Turkish" tobacco from the Cape Province was regarded by experts as very promising. During the year three papers on geological and mineralogical questions, and one on the synthesis of caoutchouc, were contributed to scientific journals by members of the staff of the institute.

\section{EXHIBITION OF MODEL AND EXPERI MENTAL ENGINEERING.}

MR. PERCIVAL MARSHALL and those who are acting with him are to be congratulated on the success of the third biennial exhibition of model and experimental engineering. As before, this is held at the Royal Horticultural Hall, and it closes next Saturday. Model engines and boats, both sailing and steam, and kites, have always supplied an unfailing attraction to the younger generation; but now the amateur mechanic and experimentalist has a wider and more attractive field, largely dependent on the gas or petrol engine, a field in which in the last two years enormous strides have been made. Aëroplanes and hydroplanes of model size are doing wonders, though, of course, in most cases the engine of the aëroplane is made of elastic. The gyroscope and electricity afford more subject-matter for the experimentalist, as the model engineer now so often becomes, to work upon. Even wireless telegraphy is not outside his reach. When it is realised that a speed of more than twenty miles an hour has now been reached by a model "speed boat," and about half a No. 2 Igo, voL. 87$]$ mile has been traversed by a model aëroplane, it must be feit that the model engineering and experimental art as fostered by the society for which Mr. Marshall is doing so much is more than mere toy-making-it has a valuable educational influence.

It may be said that there are two types of small machine or model, one the faithful copy on a small scale of the big machine, and the other the small machine made so as itself to be as good as possible as a working machine. The two ideals are wholly distinct; each has its attractive side, each is well represented at the exhibition; but it is the second that is the most instructive, and this appeals most to the scientific imagination. While the visitor cannot help admiring the model of an engineering workshop with its steam engine, shafting, travelling crane, lathes, shapers, and planing machines, all beautifully made, and with leg vices, spanners, and small tools all in keeping, and while so beautifully made a model is quite instructive, model machines made not a bit like their large prototypes, but with their proportions altered so as to make them work as well as possible, are more interesting. They may fail in appealing to the æsthetic sense, if that be the sense which makes scale models so attractive, but if so they satisfy the reasoning faculty and experimental sense, and to the writer they appear the more important. Of course, at times proportions become so wildly inverted as to lead to a ludicrous appearance; but that only indicates the triumph of reason over the imitative art. For instance, there is a model petrol engine with pressure tank, carburettor, and engine in which the proportion of carburettor and cylinder irresistibly remind one of Lear's " young bird in that bush."

The only regret, and this is expressed not for the first time, is that Mr. Marshall so far has been unable to organise his exhibition at a time of year when boys are having their holidays.

\section{FORTHCOMING BOOKS OF SCIENCE.}

I $\mathrm{N}$ addition to the books announced in NATURE of October 5 , the following works may be expected :-

\section{Agriculture.}

$W$. H. and L. Collingridge.-Manures for Garden and Farm Crops, W. Dyke. John Murray.-A new edition of Elements of Agriculture : a Text-book Prepared under the Authority of the Royal Agricultural Society of England, by the late Dr. W. Fream, edited by Prof. J. R. AinsworthDavis, illustrated.

\section{ARCH AEOLOGY.}

Cambridge University Press.-The Thunderweapon in Religion and Folklore: a Study in Comparative Archæology, Dr. C. Blinkenberg, illustrated. Oxford University Press.-Four Years' Excavations at Thebes, the Earl of Carnarvon and $\mathrm{Mr}$. Howard Carter, with chapters by $\mathrm{Mr}$. F. L. Griffith, M. George Legrain, Dr. Moller, Prof. Newberry, and Prof. Spiegelberg, illustrated.

\section{Brology.}

Blackie and Son, Ltd.-Methodical Nature Study, W. J. Claxton, illustrated. Gebrïder Borntraeger (Berlin).-Die Wirbeltiere, Prof. O. Jaekel, illustrated; Symbolae Antillanae seu fundamenta florae Indiae Occidentalis, edited by I. Urban, Band iv., fasc. 4; Flora von Steiermark, Dr. A. von Hayek, Band ii., Heft 1 ; Handbuch der systematischen Botanik, Prof. E. Warming, new edition by Prof. M. Möbius; Kulturpflanzen und Haustiere in ihrem Ubergange aus Asien nach Griechenland und Italien sowie in das übrige Europa, V. Hehn, new edition, edited by Prof. O. Schrader. Cambridge University Press.Types of British Vegetation, by members of the Central Committee for the Survey and Study of British Vegetation, edited by A. G. Tansley, illustrated; The Vegetation of the Peak District, Dr. C. E. Moss; Life in the Sea, J. Johnstone; Heredity and Eugenics, edited by J. M. Coulter; American Permian Vertebrates, S. W. Williston, illustrated. $W$. H. and L. Collingridge.-Orchids for Amateurs, C. A. Harrison, illustrated; Rock Gardens and Alpine Plants, 